В.Ю. Богданович ${ }^{1}$, А.М.Сиротенко ${ }^{2}$, О.В. Дублян ${ }^{1}$

${ }^{1}$ Центральний науково-дослідний інститут Збройних Сил Украӥни, Київ, Украӥна

${ }^{2}$ Національний університет оборони України ім. I. Черняховського, Київ, Україна

\title{
КОНЦЕПЦІЯ АСИМЕТРИЧНОЇ ПРОТИДІЇ ВОРОЖІЙ ДЕРЖАВІ ДЛЯ НЕЙТРАЛІЗАЦІЇ ІЇ ВПЛИВУ НА ВИЗНАЧАЛЬНІ СФЕРИ НАЦІОНАЛЬНОЇ БЕЗПЕКИ УКРАЇНИ (I частина)
}

У статі обгрунтувані концептуальні положення організації асиметричної протидії агресії “потужноі” у воєнному відношенні держави з боку держави-жертви агресії в інтересах захисту своїх фундаментальних життсво важливих національних інтересів. Визначені організаційно-методичні основи забезпечення достатнього рівня воєнної безпеки держави з використанням асиметричних дій, а також цілі, форми й способи організачії та ведення асиметричних дій, спрямованих на зниження впливу окремих загроз на визначальні сфери життєдіяльності держави. Приведений опис узагальненої моделі гібридної агресії (війни) та концептуальної моделі ітераційного формування потенціалу асиметричної протидії загрозам воєнній безпеці держави.

Ключові слова: асиметрична протидія, військова сила, воєнна безпека, загроза, збройний конфлікт, силовий тиск, ефективність протидії.

\section{Вступ}

Постановка проблеми у загальному вигляді. Стаття присвячена загальній проблемі підвищення ефективності забезпечення воєнної безпеки держави.

Політика національної безпеки України грунтується на повазі до норм і принципів міжнародного права. Україна захищатиме свої фундаментальні цінності, визначені Конституцією та законами України, а саме: незалежність, територіальну цілісність і суверенітет, гідність, демократію, людину, iї права і свободи, верховенство права, забезпечення добробуту, мир та безпеку [1].

Усунення загроз державному суверенітету та створення умов для відновлення територіальної цілісності України у межах міжнародно визнаного державного кордону України, гарантування мирного майбутнього України потребує якісно нової державної політики, спрямованої на ефективний захист національних інтересів у визначальних сферах життєдіяльності держави [2]. Це обумовлює необхідність нейтралізації деструктивних впливів на всі сфери забезпечення національної безпеки. В сучасних умовах воєнно-політичної обстановки довкола України виконання цього завдання стає можливим шляхом впровадження технологій підготовки та ведення асиметричної протидії більш сильному у воєнному та економічному відношенні противнику.

Аналіз останніх досліджень і публікацій. Основна термінологія національної безпеки була визначена у Законі України “Про основи національної безпеки України” [3] (втратив чинність у 2018 році).
Окремі визначення були уточнені у законі України “Про національну безпеку України” [4].

На наш погляд, інтереси безпеки на даному етапі превалюють над іншими пріоритетами, оскільки саме на основі їх реалізації можна генерувати сценарії сталого розвитку держави. Пріоритети інтересів безпеки базуються на визначених стратегічних завданнях країни щодо іiі розвитку на вибрану перспективу. Стратегія національної безпеки України визначає організаційні основи забезпечення достатнього рівня воєнної безпеки держави [1] та є основою для комплексного планування діяльності органів державної влади у сфері національної безпеки і оборони, а також розроблення інших документів, якими визначаються цілі, напрями і механізми діяльності органів державної влади у зазначеній сфері. Це потребує розроблення концептуальних підходів протидії більш сильній у воєнному та економічному відношенні державі, що систематично здійснює деструктивний вплив на забезпечення національної безпеки України.

Формулювання мети статті. Метою статті є обгрунтуваня окремих положень Концепції асиметричної протидії ворожій державі для нейтралізації іiі впливу на визначальні сфери національної безпеки України.

\section{Виклад основного матеріалу}

Структурно запропонована Концепція асиметричної протидії ворожій державі для нейтралізації іiі впливу на визначальні сфери національної безпеки України (далі - Концепція) містить сім структурних елементів: 
1. Організаційно-методичні основи забезпечення достатнього рівня воєнної безпеки держави з використанням асиметричних дій щодо деескалації окремих загроз воєнного та гібридного характеру.

2. Цілі, форми й способи організації та ведення асиметричних дій, спрямованих на зниження впливу окремих загроз на визначальні сфери життєдіяльності держави.

3. Узагальнена модель гібридної агресії (війни).

4. Концептуальна модель ітераційного формування потенціалу асиметричної протидії загрозам воєнній безпеці держави.

5. Структурно-логічна послідовність та принципи організації протидії інформаційно-психологічним впливам з боку недружньої держави.

6. Концептуальний підхід до формування замислу локальної спеціальної операції асиметричної протидії та визначення часткових завдань суб'єктам, що залучаються до неї.

7. Базові засади оцінювання результативності проведення локальної спеціальної операції асиметричної протидії в інтересах забезпечення достатнього рівня воєнної безпеки держави.

Ця публікація містить опис перших трьох структурних елементів Концепції.

1. Організаційно-методичні основи забезпечення достатнього рівня воєнної безпеки держави $з$ використанням асиметричних дій щзодо деескалачіi окремих загроз воєнного та гібридного характеру

Розвиток Збройних Сил, інших військових формувань має здійснюватися на основі кращих досягнень провідних армій світу, а також власного бойового досвіду останніх років. Необхідно осмислити його та творчо враховувати в нових настановах i бойових статутах.

Чинна нормативно-правова база 3 питань національної безпеки визначає, що виявлені загрози воєнного характеру повинні усуватися чи нейтралізовуватися передусім невійськовими (політичними, економічними, інформаційно-психологічними та іншими) методами й засобами, а у разі їх низької ефективності - 3 використанням воєнно-політичних, воєнно-технічних, спеціальних та інших методів i засобів для забезпечення достатнього рівня воєнної безпеки держави. Основними невоєнними інструментами реалізації цих завдань мають бути [5]:

зважена політика забезпечення достатньої обороноздатності;

оновлення гарантій безпеки, наданих Україні за добровільну відмову від ядерної зброї;

взаємовигідне стратегічне партнерство;

проведення активних заходів в інформаційному просторі;

ефективна співпраця 3 міжнародними організаціями та союзами на основі балансу інтересів тощо.

Зазначені невоєнні інструменти можуть вико- ристовуватися при плануванні асиметричної протидії загрозам реалізації національних інтересів.

Основними принципами залучення невоєнних інструментів для асиметричної протидії доцільно визначити:

1. Достатність сформованого потенціалу асиметричної протидії.

2. Комплексна вразливість держави-джерела загроз.

3. Нарощування “потужності” протидії за рахунок використання коаліційної протидії недружній державі.

4. Швидкоплинність реалізації асиметричних заходів.

5. Максимізація шкоди недружній державі у різних сферах життєдіяльності до такого рівня, який би спонукав недружню державу до припинення деструктивних дій проти держави-мішені.

6. Гіпертрофія завданих збитків недружній державі в очах світової спільноти.

7. Скритність і мінімізація ознак державної приналежності (легендування) операцій асиметричних дій.

Політика достатньої обороноздатності потребує швидких і рішучих дій щодо розвитку сектору безпеки і оборони України (СБОУ).

Фінансування українського сектору безпеки 3 розрахунку на одного співробітника у три рази менше, ніж у Російській Федерації, і на порядок нижче, ніж у країнах НАТО, що має враховуватися під час нормативного визначення рівня достатньої обороноздатності.

На наш погляд, основну увагу слід зосередити на автоматизації та інформаційно-аналітичному забезпеченні управління асиметричною протидією загрозам воєнного та гібридного характеру в інтеpecax забезпечення визначеного рівня воєнної безпеки держави.

Для вироблення і прийняття рішень щодо асиметричної протидії загрозам воєнній безпеці потрібна достовірна і своєчасна інформація про реальний стан суб'єктів сектору безпеки і оборони та загрози, що потребують нейтралізації.

На думку експертів [6-9 ], у діяльності органів державного управління не склалася цілісна система інформаційно-аналітичного забезпечення підтримки прийняття рішень для забезпечення визначеного рівня національної (воєнної) безпеки. Існуючі інформаційні та аналітичні структури держави не об'єднані в єдину інформаційну мережу, використовують різні методики для проведення розрахунків та мають недостатній рівень автоматизації процесу управління суб'єктами сектору безпеки і оборони у кризових ситуаціях.

Залежно від наявності загроз воєнній безпеці характер інформації, яка потрібна для прийняття 
органами державної влади рішень в інтересах підтримання необхідного рівня національної (воєнної) безпеки держави, швидко змінюється, а масив інформації, що потребує обробки й аналізу, може бути необмежений. Усе це потребує створення національної системи інформаційно-аналітичного забезпечення й автоматизації управління процесом забезпечення воєнної безпеки держави.

Такий підхід дасть змогу розширити можливості системи забезпечення воєнної безпеки України для підтримання стабільності в умовах дії більш широкого спектра загроз.

Виходячи із сутності інформаційно-аналітичного забезпечення як одного із видів інформаційного забезпечення [8], система інформаційно-аналітичного забезпечення організаційно має бути єдиним контуром взаємодіючих структур, які здійснюватимуть інформаційно-аналітичну підтримку прийняття рішень [10-11].

Метою функціонування системи має бути завчасне виявлення причин, умов і ознак загроз воєнного та гібридного характеру й інформування особи, яка приймає рішення, для своєчасного запровадження адекватних заходів військового і невійськового характеру для їх нейтралізації.

Органи державного і військового управління здебільшого зайняті підготовкою та реалізацією оперативних рішень поточних проблем воєнної безпеки. Відсутні довгострокові прогнози розвитку ситуації, а середньострокові мають описовий характер, відсутні сценарії розвитку обстановки в окремих сферах національної безпеки та їх вплив на воєнну сферу з опорою на обгрунтовані критерії і показники. Це насамперед пов'язано з принциповими теоретичними труднощами, обумовленими відсутністю об'єктивних моделей та методик, які з високим рівнем достовірності й адекватності давали б змогу описувати та досліджувати складні процеси в умовах неповної, недостовірної та неточної інформації.

Водночас потенціал існуючих ситуаційних центрів використовується неповною мірою, а можливості сучасних технічних засобів оброблення i транспортування даних в єдиному форматі в інтеpecax усіх суб'єктів сектору безпеки і оборони є недостатніми. Зважаючи на це, виникає необхідність розроблення рекомендацій для реалізації повноцінного та адекватного інформаційно-аналітичного забезпечення процесу протидії сучасним загрозам.

Важливе значення має й аналітична складова інформаційно-аналітичного забезпечення управління інтегрованим потенціалом протидії загрозам воєнного характеру, яка повинна забезпечити [6]:

обгрунтованість рішень завдяки застосуванню ефективних методів обробки та аналізу інформації;

оперативність виконання завдань аналізу, оцінювання та прогнозування сценаріїв проведення спеціальних операцій асиметричного характеру.

Для цього в структурі аналітичного рівня системи інформаційно-аналітичного забезпечення та автоматизації управління асиметричними діями пропонується мати комплекс взаємозв'язаних моделей, а саме:

воєнно-політичну модель держави;

модель загроз воєнній безпеці держави;

модель системи моніторингу загроз воєнній безпеці держави;

модель оцінювання рівня воєнної небезпеки і можливостей щодо його деескалації;

модель оцінювання потрібного потенціалу силових і несилових сил та засобів для реалізації задуму спеціальної операції;

модель формування множини варіантів груп суб'єктів, що залучаються до асиметричної протидії виявленим загрозам.

Комплекс взаємозв'язаних моделей доцільно реалізувати в розроблюваних інструментальних засобах аналізу для моделювання процесів формування та розподілу стратегічних завдань між суб'єктами СЗНБ для їх використання при проведенні асиметричних заходів протидії.

На превеликий жаль, на практиці наукове обгрунтування пропозицій і рекомендацій щодо прийняття управлінських рішень, у тому числі і щодо асиметричного реагування на загрози, ускладнюється через недосконалість необхідного для цього науково-методичного апарату. У результаті в секторі безпеки і оборони України під час обгрунтування багатьох управлінських рішень застосовується відомий метод спроб і помилок, який істотно знижує ефективність державного управління у сфері національної безпеки. До того ж неекономно витрачаються навіть ті мізерні ресурси, які виділяються для захисту національних інтересів.

При цьому у керівних документах у сфері національної безпеки і оборони на перший план виходить вимога щодо використання асиметричних заходів та надання пріоритетності невійськовим інструментам захисту національних інтересів.

Зазначене свідчить про необхідність розроблення специфічного науково-методичного апарату обгрунтування потрібного потенціалу асиметричного реагування, виконавчих суб'єктів та їх необхідних спроможностей для досягнення заданого рівня ефективності асиметричної протидії.

Аналіз доступного методичного апарату такого обгрунтування свідчить [10], що в Україні основними вважаються метод генерації ідей (метод мозкового штурму) і методи експертного оцінювання (прогнозування). Ураховуючи військові та невійськові можливості України, специфіку забезпечення іï воєнної безпеки, методичну основу системи протидії загрозам, в умовах дії яких забезпечення необхідно- 
го рівня воєнної безпеки симетричними методами не представляється можливим, можуть скласти:

метод побудови системи асиметричної протидії агресії з боку високорозвиненої держави;

метод обгрунтування управлінського рішення на асиметричне реагування на загрози воєнній безпеці держави;

метод формування групи суб'єктів сил оборони для реалізації задуму асиметричної протидії виявленій (прогнозованій) загрозі;

метод оцінювання ефективності асиметричної протидії в системі забезпечення воєнної безпеки;

комплекс моделей та методик формування та управління потенціалом асиметричної протидії загрозам воєнній безпеці держави.

Детально зазначені складові методичного апарату обгрунтування потрібного потенціалу асиметричного реагування, виконавчих суб'єктів та їх необхідних спроможностей для досягнення заданого рівня ефективності асиметричної протидії будуть розглянуті у наступних публікаціях.

2. Цілі, форми й способи організації та ведення асиметричних дій, спрямованих на зниження впливу окремих загроз на визначальні сфери життєдіяльності держави

Однією $з$ тенденцій, які впливають на формування та розвиток безпекового середовища у світі та навколо України, є перенесення ваги у воєнних конфліктах на асиметричне застосування військової сили не передбаченими законом збройними формуваннями, зміщення акцентів у веденні воєнних конфліктів на комплексне використання військових i невійськових інструментів (економічних, політичних, інформаційно-психологічних тощо), що принципово змінює характер збройної боротьби та висуває більш високі вимоги до системи забезпечення воєнної безпеки [5].

Середовище безпеки у XXI ст., сформоване глобалізацією, виявляється якісно складнішим і потребує готовності до протидії складнішим загрозам суспільству. Аналіз головних тенденцій розвитку безпекового середовища у світі доводить, що у переважній більшості з них застосуванню військової сили відводиться важлива роль як аргументу у відносинах між країнами.

Сучасна дійсність доводить, що загрози застосування військової сили проти України не тільки існують, а вже деякі перетворилися у реальні події. I хоча ці загрози мають різні назви (воєнні загрози, загрози воєнного характеру, загрози воєнній безпеці, загрози застосування військової сили), усі вони віддзеркалюють одну сутність - застосування збройного насилля для досягнення відповідної мети. 3 огляду на це ми будемо вживати термін “загроза воєнного характеру” як такий, що відображає ширше розуміння суті таких загроз та їх безпосередній вплив на воєнну безпеку держави. Від інших загроз, які за своїми наслідками мають такий самий ефект, що й застосування військових засобів, їх відрізняє цілеспрямований характер, а не якийсь випадковий збіг обставин з тим самим ефектом.

Таким чином, цілеспрямований, адаптивний щодо держави-мішені та конкретної політичної ситуації характер загроз воєнного характеру, що поєднують у собі суто військові і цивільні складові, ми вважаємо їх основною особливістю. Саме цілеспрямований характер і висока динаміка перетворення цих загроз із категорії потенційних до реальної їх реалізації потребують ретельного попереднього опрацьовування на державному рівні з розробленням заходів щодо адекватної протидії їм.

Звідси можна сформулювати головну мету (ціль) заходів щодо протидії загрозам воєнного характеру - своєчасне виявлення загрози та недопущення перетворення іiі із потенційної до настання реальних наслідків дії формуючих загрозу чинників.

Зрозуміло, що сучасні загрози воєнного характеру, які формуються не тільки суто військовими чинниками, а й невійськовими, характеризуються різною “потужністю”, потребують такої самої комплексної адекватної реакції, на що держава-мішень не завжди може знайти необхідні ресурси. У широкому розумінні мова йде про інтеграцію зусиль військових і невійськових інструментів сил оборони (формування інтегрованого потенціалу [6]) щодо протидії тим загрозам воєнній безпеці держави, на які у неї при реагуванні симетричними способами не вистачає ресурсів. Вирішення цього завдання покладається на СБОУ.

Незважаючи на задекларовану у [2] необхідність інтеграції зусиль (сумісного залучення) складових СБОУ, організація процесу інтеграції (технологія формування інтегрованого потенціалу асиметричної протидії) не визначена, що засвідчує появу як наукової, так і організаційної проблеми. На наш погляд, визначення мети, виконавчих суб'єктів, форм та способів формування інтегрованого потенціалу асиметричної протидії загрозам воєнного характеру можна вважати одним 3 етапів вирішення зазначеної вище наукової проблеми.

Складність вирішення цієї проблеми потребує застосування системного підходу, який за своєю природою є міждисциплінарним, загальнонауковим і спрямованим на інтеграцію досягнень суспільних, природничих i технічних наук, а також досвіду практичної діяльності, насамперед в області організації та управління.

Оскільки системний підхід забезпечує розроблення концептуальних, тобто змістовних і формальних засобів відображення досліджуваних об'єктів як системи, а також побудову узагальнених моделей систем, формування вимог до їх властивостей, ціле- 
спрямованої поведінки, розвитку, ієрархічної побудови, процесів управління в системах, то його можна використати для побудови системи протидії описаним вище загрозам.

Системний підхід потребує розглядати можливу сукупність військових та невійськових сил і засобів СБОУ для протидії загрозам воєнного характеру як складну систему. В основу формування (синтезу) цієї системи, іiі інтегративних якостей покладено цілеспрямованість системи як системоутворюваного фактора. Саме визначена вище мета (цілі) такої системи, будучи об'єктивним критерієм вибору із середовища всіх елементів і відносин, що створюють систему, визначатиме необхідний склад (групу) суб'єктів СБОУ та їх функції. Подальша декомпозиція та формалізація мети створюють можливості для іiї коректного опису. По суті йдеться про створення відповідної системи протидії загрозам воєнного характеру. Слід зазначити, що для кожної загрози створюватиметься своя система протидії.

Таким чином, з огляду на сутність загрози воєнного характеру, метою інтеграції військових і невійськових сил та засобів для асиметричної протидії цим загрозам $є$ таке організаційне поєднання сил $\mathrm{i}$ засобів суб’ єктів СБОУ, які б у разі застосування за умов єдиного керівництва та відповідного планування були би здатні ефективно зменшити дію чинників, що формують таку загрозу, до прийнятних значень.

Декомпозиція зазначеної мети із застосуванням одного $з$ методів побудови системи цілей - побудови “дерева” иілей (підиілей) з асиметричної протидії загрозі воєнного характеру, дасть змогу вибудовувати взаємозв'язки між цілями різних рівнів, поділяти великі цілі на етапи, надавати чітку загальну картину системи цілей.

Кількість складових (підцілей) головної мети та їх ієрархічних рівнів залежатиме від обраної стратегії протидії загрозі, можливостей залучених до протидії суб'єктів СБОУ та їх структурних підрозділів за підпорядкуванням. Таке “дерево” цілей зв’язує воєдино довго- і короткострокові цілі, що дає змогу бачити загальну стратегічну картину асиметричної протидії. При цьому можна виокремити такі види цілей:

стратегічні - формуються під час визначення довготривалого процесу протидії загрозам;

тактичні - формуються для вирішення оперативних завдань суб'єктам СБОУ;

траєкторні - визначають загальний напрям, у якому має змінюватися об'єкт впливу (чинник або група чинників, що формують загрозу).

Під час формування “дерева” цілей дотримуються таких основних вимог, як виключення неважливих та малоефективних заходів і заходів, виконанню яких перешкоджає недостатність ресурсів.
Основними системними вимогами до переліку підцілей найнижчого рівня є класичні - їх повнота, ненадлишковість та вимірність. Саме вимірність цілей уможливлює пошук оптимального (раціонального) розподілу зусиль між суб'єктами СБОУ та організацію контролю за результатами їхніх дій на всіх етапах протидії загрозам.

Проте, зважаючи на специфічність суб'єктів СБОУ (різних за функціями та підпорядкованістю у загальній системі державних органів, наявність недержавних організацій), слід очікувати, що на відміну від технічних та організаційних систем у створюваній системі протидії конкретній загрозі за рахунок військових та невійськових сил і засобів вимірність цілей забезпечити буде дуже важко.

Таким чином, ураховуючи те, що формування “дерева” цілей буде визначальним для організації процесу інтеграції військових і невійськових сил та засобів щодо протидії загрозам воєнного характеру, це питання потребує детальнішого розгляду.

Слід зазначити, що протидія загрозам воєнного та гібридного характеру є складним процесом, що зумовлено великою кількістю формуючих загрози різнорідних чинників та складністю прогнозу змін інтенсивності їхньої дії.

Потребує суттєвого удосконалення науковометодичний апарат аналізу безпекового середовища, виявлення та оцінювання рівня загроз воєнного та гібридного характеру, визначення необхідних ресурсів, потрібного часу і рівня деескалації загрози та формування необхідної для цього групи суб'єктів сил оборони, а також їх потрібних спроможностей для формування потенціалу асиметричної протидії щодо завдання противнику неприйнятного збитку, в т.ч. і в невійськових сферах. Звісно, що така діяльність суб'єктів сил оборони потребує визначення притаманних процесу протидії специфічних форм i способів їх застосування. Як і у воєнному мистецтві, форми і способи застосування визначених суб'єктів сил оборони будуть залежати від противника, обстановки, що склалася, наявних сил і засобів, їх можливостей, якісних характеристик кадрів, на які покладатимуться розроблення як загальної стратегії асиметричних дій, так і постановка та виконання конкретних завдань.

Якщо підсумувати все вищенаведене, можна запропонувати кілька основних способів формування інтегрованого потенціалу асиметричної протидії:

інтеграція військових і невійськових сил та засобів із наданням пріоритету несиловим засобам із застосуванням силових для підтримки;

інтеграція військових і невійськових сил та засобів із наданням пріоритету силовим засобам із застосуванням несилових для підтримки.

Зрозуміло, що кожен із зазначених способів інтеграції може мати безліч варіантів конкретного 
переліку застосованих сил і засобів суб'єктів сил оборони та ступеня їх участі у асиметричній протидії загрозі з плином часу.

Ми вважаємо, що більш глибокий розгляд способів інтеграції військових і невійськових сил та засобів для протидії загрозам воєнного характеру потребує окремого дослідження.

Щодо форм застосування вибраних суб'єктів для асиметричної протидії, то пропонується використовувати термін “спеціальна операція", як “координовані дії різнорідних сил та засобів, що об'єднані єдиною метою”.

Тобто “спеціальна операція" стає формою досягнення стратегічної мети протидії вибраній загро3i. Ïї складовою може бути “локальна спеціальна операція", як форма досягнення однієї з тактичних цілей протидії, тому що є локальною, конкретною за метою чи цілями, а тому обмеженою за часом і гравцями формою асиметричної протидії вибраній загрозі як воєнного так і гібридного характеру.

Ураховуючи той факт, що загрози воєнного та гібридного характеру формуються багатьма різними чинниками, окреслені форми і способи інтеграції військових і невійськових сил та засобів можуть мати велику кількість варіантів та не завжди бути беззаперечними.

\section{3. Узагальнена модель гібридної агресії (війни)}

Розвиток процесів глобалізації суттєво впливає як на геополітичні інтереси держав, так і на погляди на шляхи їх реалізації. У повній мірі це стосується насамперед забезпечення воєнної безпеки, як безпекового аспекту геополітичних інтересів. Головним чинником глобальної системи вважаються найрозвинутіші країни світу, які фактично експлуатують менш розвинуті, яких вони вважають напівпериферією або периферією. Важливим стає те, що у глобальній світовій системі потенціал розповсюдження небезпек (загроз, конфліктів, криз, агресій) значно вищий.

Глобалізація надає можливість найрозвинутішим країнам значно посилити дію традиційних методів впливу на світові процеси у своїх геополітичних інтересах та запроваджувати нові, які відповідають сучасності. Збройні сили держав та їх зброя разом $з$ дипломатією й пропагандою були і залишаються важливим інструментом зовнішньополітичної діяльності.

Для сучасних воєн, які отримали назву “гібридних", характерним є не використовувані засоби, а цілі, що досягаються, які зіставні з цілями, що зазвичай визначаються в ході традиційних воєн, наприклад, знищення, розграбування, окупація, зміна режиму, занурення в хаос тощо.

Однією 3 найважливіших відмінностей “гібридної” війни $є$ те, що вона відбувається не стільки за володіння територіями і природними ресурсами, скільки 3 прагненням контролювати настрій громадян країни-мішені завдяки контролю за інформаційним простором і промиванню мізків населенню на іiі ж території.

Завдяки вживаним технологіям на сучасному етапі зазначені вище цілі можуть бути досягнуті без застосування летальної зброї. Ще одним інструментом для реалізації своїх геополітичних інтересів $\epsilon$ примушення країни до збройного конфлікту з вибраним для знищення (ослаблення) супротивником. У цьому разі починають відігравати істотну роль політичні чинники.

В останні десятиліття “гібридні” війни розгортаються переважно в ментальному просторі. Державу можна знищити, не оголошуючи їй війни і не ведучи проти неї традиційних військових операцій, а лише використовуючи політичні, інформаційні та психологічні засоби. Таких способів багато. Наприклад, революція, перепрограмування свідомості правлячої еліти на антидержавницький курс, зміна режиму і встановлення маріонеткового уряду, який, виконуючи волю агресора, діє в антинаціональних інтересах і знищує державність. У цілому всі ці способи зводяться до дії на владу або силовими методами (революція), або несиловими - шляхом насадження корупції або іiї формування з уже корумпованих осіб чи заздалегідь підготовлених агентів впливу [12]. У будь-якому випадку тут підключається зовнішня сила, що реалізує чинник зовнішнього управління [13]. Стратегія “гібридноі” війни націлена на виснаження країни-мішені й будується на використанні широкого спектру дій, здійснюваних 3 використанням військових i невійськових формувань. При цьому держава-агресор приховано, без формального оголошення війни атакує структури державного управління, економіку, інформаційну й культурно-світоглядну сфери, сили правопорядку та регулярну армію країни-мішені. Для збройних провокацій та зіткнень 3 силовими структурами залучаються місцеві заколотники, найманці, незаконні військові формування, націоналістичні й псевдорелігійні організації, які фінансуються 3-за кордону. На повалення правлячого режиму активно працюють дипломатичні відомства й розвідувальні структури країни-агресора.

Одним із завдань “гібридної” агресії є втягнення держави-мішені в локальні конфлікти у прикордонних районах і стратегічно важливих регіонах, в першу чергу з суперниками держави-агресора, щоб “чужими” руками ослабити своїх конкурентів.

Завершення “гібридноі” війни являє собою складну проблему, обумовлену особливостями інформаційної війни як складової частини цієї війни. Посіяні “щедрою” рукою насіння взаємної недовіри й ворожнечі будуть давати отрутні сходи протягом 
багатьох десятиліть, провокувати міжнаціональне й міжрелігійне протистояння. Не відразу складуть зброю й підтримувані закулісними гравцями найманці із усього світу, для яких війна є “мамою рідною”.

У “гібридній” війні наслідок використання непрямих методів, пов'язаних із введенням санкцій, нарощуванням силового тиску, цілеспрямованим руйнівним ІПВ на свідомість правлячих еліт і всього населення країни, створенням і підтримкою іррегулярних збройних формувань, залученням сил спеціальних операцій, участю організованої злочинності й терористичних угруповань, створюють украй небезпечну, непідконтрольну ініціаторам ситуацію. Прямий зв'язок між причиною й наслідками порушується. У результаті створюються великі зони невизначеності, пов'язані з діями різнорідних акторів, що найчастіше не координують свої плани, а дії одного з них можуть викликати лавинодібні зміни всієї воєнно-стратегічної й політичної обстановки. Ці й деякі інші фактори створюють серйозні перешкоди при спробах передбачити хід і результат “гібридної” війни. Поява нових витончених форм агресії обумовлює необхідність завчасного створення механізмів нейтралізації негативного впливу зовнішніх втручань і внутрішніх екстремістських дій за рахунок зміцнення громадянського суспільства, консолідації союзників і партнерів, захисту національних цінностей і національних інтересів як факторів внутрішньої мобілізації для протистояння кольоровим революціям і “гібридним” війнам. Особлива увага повинна приділятися випереджальним розробкам, націленим на адаптацію до військових потреб деяких сучасних інформаційних і гуманітарних технологій. Оскільки сьогодні “гібридна" війна перетворилася в нову форму міждержавного протиборства, то вивчення цього феномену є актуальним науковим завданням. Питання протидії “гібридній” агресії повинні бути виділені в якості одного із пріоритетних напрямків військово-наукових досліджень, і першим кроком на цьому шляху має бути розробка моделі “гібридної” агресії [14].

Формальне представлення “гібридноі” агресії у вигляді орієнтованого графу дає змогу враховувати iii просторово-часовий характер, оцінювати окремі параметри та характеристики “гібридних" атак, сил та засобів, які можуть бути використані при здійсненні агресії проти держави-мішені. Кінцевою метою “гібридної” агресії є встановлення зовнішнього управління над державою-мішенню.

4. Конщептуальна модель ітераційного формування потенціалу асиметричної протидї загрозам воєнній безпеці держави

В умовах реформування сектору безпеки і оборони України актуальним є раціональне використання наявних сил та засобів. Для протидії загрозам, що потребують значних зусиль воєнного характеру (наприклад, співвідношення воєнних потенціалів 1:10), ресурсів, яких держава не може знайти, мінімально необхідного часу для нейтралізації виявленої (прогнозованої) загрози тощо, можуть бути використані асиметричні дії. Асиметричні дії притаманні конфліктній ситуації, у якій заходами економічного, дипломатичного, інформаційного та безпосередньо воєнного характеру більш слабкий противник проводить асиметричну стратегію (тактику) ведення збройної боротьби, відповідно до наявних у нього обмежених ресурсів для нівелювання воєннотехнологічних переваг сильної сторони.

Важливою умовою ефективності проведення асиметричних дій $є$ точне визначення найбільш уразливих і слабких місць противника, вплив на які дасть максимальний ефект за мінімальних затрат власних сил і ресурсів.

Зазначене обумовлює необхідність розроблення концептуальної моделі формування потенціалу асиметричної протидії загрозам воєнній безпеці держави (загрози воєнного і гібридного характеру) (рис. 1), яка б давала змогу формувати необхідний потенціал асиметричної протидії загрозам для забезпечення визначеного у правовому просторі держави рівня воєнної безпеки держави та задоволення прийнятих ресурсних обмежень [6].

У Концепції розвитку сектору безпеки і оборони України визначені такі першочергові завдання реформування СБОУ:

об'єднання оперативних спроможностей складових СБОУ для забезпечення своєчасного й адекватного реагування на кризові ситуації, які загрожують національній безпеці;

створення ефективної системи управління СБОУ як цілісною функціональною системою;

постійне підтримання визначених сил безпеки й оборони в готовності до виконання завдань за призначенням;

удосконалення системи планування у СБОУ, забезпечення раціонального використання державних ресурсів та мінімізація збитків національного багатства.

Досягнення необхідних спроможностей СБОУ щодо забезпечення визначеного рівня воєнної безпеки держави потребує розроблення відповідної науково-методологічної бази та науково-методичного забезпечення цього процесу. Слід зазначити, що в сучасних умовах саме через відсутність системних досліджень i науково обгрунтованої практики щодо розв'язання проблем воєнної безпеки виявляється недостатня результативність здійснюваних заходів у сфері оборони і створюваних для їх реалізації державних і недержавних організацій та структур. 


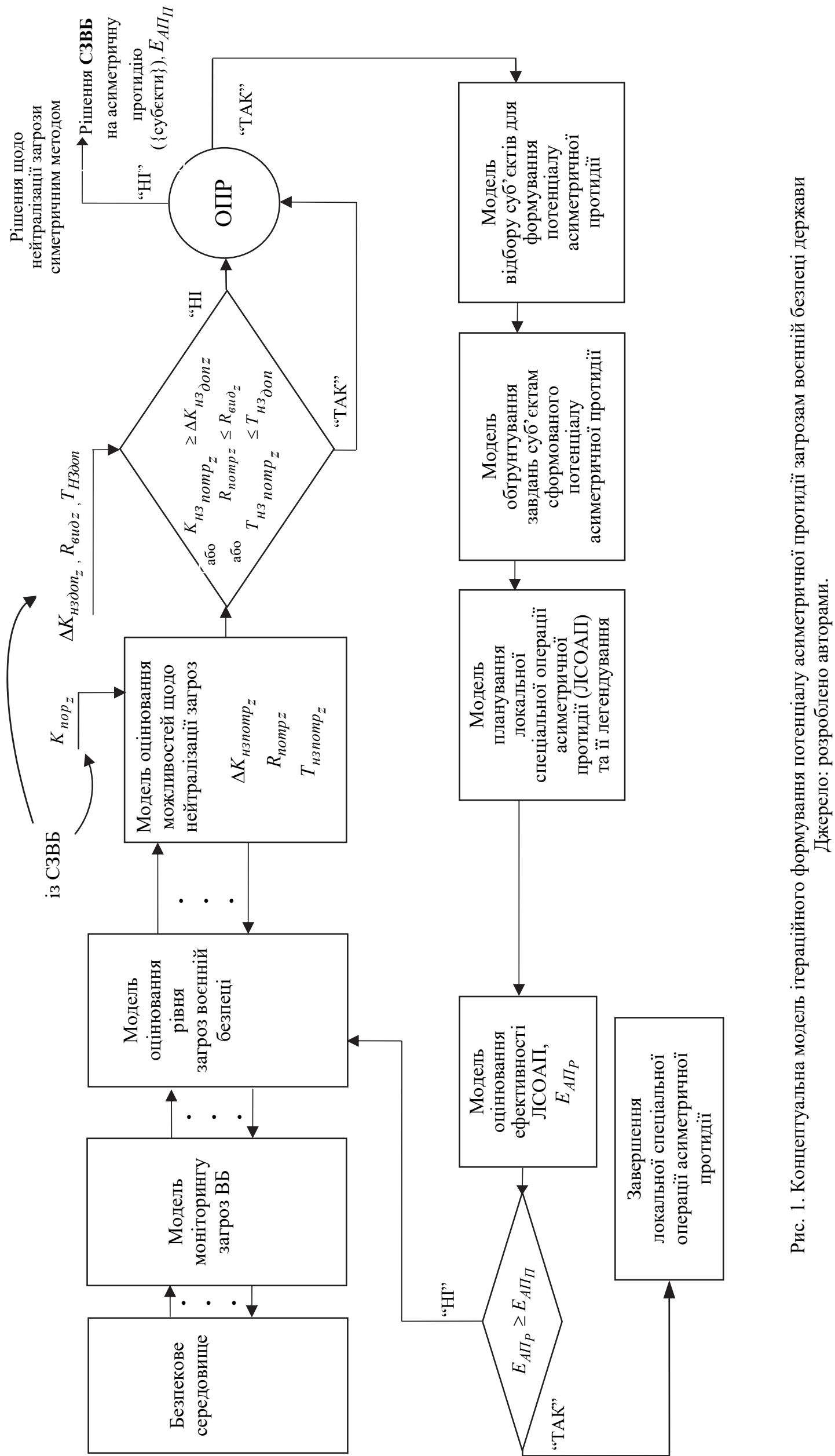


Це обумовлює необхідність проведення дослідження з використанням відповідних методик (моделей), серед яких чільне місце відводиться концептуальній моделі ітераційного формування потенціалу асиметричної протидії (КМІФПАП) загрозам воєнній безпеці [6]. КМІФПАП може використовувати вище військово-політичне керівництво держави в ситуаційних центрах управління під час планування й проведення цілеспрямованої політики із забезпечення необхідного рівня воєнної безпеки держави, а також у навчальних, наукових і дослідних установах під час вивчення кризових ситуацій і шляхів виходу 3 них. У ролі асиметричних дій можуть виступати дії Сил спеціальних операцій, зовнішньої розвідки, різні форми інформаційного впливу, а також політичні, економічні та інші невійськові види впливу. Вхідними даними КМІФПАП є результати аналізу безпекового середовища на предмет зародження або існування небезпечних явищ, потенційних та реальних загроз національним інтересам, в умовах яких держава реалізує свою політику національної безпеки [6].

Ефективність реалізації асиметричних дій залежить від повноти і своєчасного їх виконання, що досягається скоординованими по цілях, місцю і часу діями різновідомчих сил всієї організації держави. Успішність асиметричних дій буде залежати від:

якості та повноти планування локальної спеціальної операції (ЛСО);

рівня професійної підготовки особового складу підрозділів, що залучаються;

рівня інформаційної підтримки ЛСО;

повноти та своєчасного ресурсного та інших видів забезпечення ЛСО на всіх етапах ії проведення тощо.

Концептуальна модель ітераційного формування потенціалу асиметричної протидії загрозам воєнній безпеці дає змогу вирішувати як пряме завдання щодо розрахунку реальних можливостей держави щодо забезпечення воєнної безпеки, так і зворотне завдання, що забезпечує розрахунок необхідного потенціалу сил та засобів для забезпечення нормативно встановленого рівня воєнної безпеки держави [15-16].

Основним бажаним результатом асиметричної протидії має стати відмова противника від активних воєнних дій, тобто деескалація загрози воєнного або гібридного характеру до прийнятного (допустимого) рівня [17-19].

Якщо за результатом моніторингу досягнення потрібного рівня воєнної небезпеки не відбувається (умова "НІ"), то впроваджена в моделі технологія зворотного зв'язку дозволяє перейти до формування іншого варіанту інтегрованого потенціалу асимет- ричної протидії і повторення описаних вище обчислювальних, логічних і порівняльних процедур.

Запропонована концептуальна модель формування потенціалу асиметричної протидії загрозам воєнній безпеці держави дає змогу реалізувати нові підходи до застосування військових і невійськових сил та засобів щодо нанесення противнику неприйнятного збитку, в т.ч. і в невійськових сферах безпеки, і тим самим примусити навіть більш сильного у воєнному відношенні противника відмовитися від застосування військової сили проти держави-жертви агресії. Крім того, концептуальна модель дає можливість не тільки обгрунтовувати раціональний склад сил і засобів для деескалації виявлених (прогнозованих) загроз, оцінювати реальні можливості щодо нейтралізації конкретних загроз воєнного характеру згідно $з$ прийнятими в державі стратегіями забезпечення воєнної безпеки, а й оцінювати результативність окремих суб'єктів сектору безпеки і оборони, що залучаються до процесів деескалації загроз державі.

\section{Висновки}

Концепція асиметричної протидії ворожій державі спрямована на нейтралізацію іiї деструктивного впливу на забезпечення національної безпеки слабішої у воєнному та економічному відношенні країни шляхом впровадження технологій підготовки та ведення асиметричної протидії. Концепція містить організаційно-методичні основи забезпечення достатнього рівня воєнної безпеки держави з використанням асиметричних дій щодо деескалації окремих загроз воєнного та гібридного характеру, сформульовано основні цілі, визначено форми й способи організації та ведення асиметричних дій, спрямованих на зниження впливу окремих загроз на визначальні сфери життєдіяльності держави.

Організаційно-методичні основи забезпечення необхідного рівня воєнної безпеки держави 3 використанням асиметричних дій щодо деескалації загроз, в умовах дії яких забезпечення необхідного рівня воєнної безпеки симетричними методами не представляється можливим, дають змогу здійснювати наукове обгрунтування організації та формування системи протидії зазначеним загрозам асиметричними методами.

Запропоновані цілі, форми й способи організації та ведення асиметричних дій, спрямованих на зниження впливу окремих загроз на визначальні сфери життєдіяльності держави можна, вважати подальшим розвитком методології забезпечення воєнної безпеки держави.

У наступній публікації буде продовжений опис структурних елементів запропонованої Концепції. 


\section{Список літератури}

1. Указ Президента України "Про Стратегію національної безпеки України” № 287/2015 від 06.05.2015 р. - К., 2015. $-45 \mathrm{c}$.

2. Указ Президента України “Про рішення Ради національної безпеки і оборони України від 04.03.2016 “Про Концепцію розвитку сектору безпеки і оборони України” № 92/2016 від 14.03.2016 р.” - К., 2016. - 17 с.

3. Закон України “Про основи національної безпеки” № 964-IV від 19.06.2003 р. (із змінами, внесеними згідно із Законом № 186-VIII від 12.02.2015) // Законодавство України з питань військової сфери. - К. : Урядовий кур’єр. - 2015. - № 15.

4. Закон України “Про національну безпеку України” № 2469-VIII від 21 червня 2018 // Законодавство України 3 питань військової сфери. - Голос України, 2018. - № 122 (6877). - Київ, 2018. - 31 с.

5. Указ Президента України "Про рішення Ради національної безпеки і оборони України від 02.09.2015 “Про нову редакцію Воєнної доктрини України” № 555 від 24.09.2015. - К., 2015. - 24 с.

6. Методологія комплексного використання військових і невійськових сил і засобів сектора безпеки і оборони для протидії сучасним загрозам воєнній безпеці України: монографія / В.Ю. Богданович, І.С. Романченко, І.Ю. Свида, А.М. Сиротенко. - К.: НУОУ ім. І. Черняховського, 2019. - 268 с.

7. Богданович В.Ю. Теоретико-методологічні основи забезпечення національної безпеки України: моногр. / В.Ю. Богданович, І.Ю. Свида, Є.Д. Скулиш; у 7 т., Т. 4: Воєнна безпека України та шляхи її забезпечення. - К.: Наук.вид. відділ НА СБ України, 2012. - 464 с.

8. Саричев Ю.О. Інформаційно-аналітичне забезпечення як вид інформаційного забезпечення в системі державного управління / Ю.О. Саричев // Вісник НАДУ при Президентові України (Серія “Державне управління”). - 2017. - № 3. C. $120-126$.

9. Богданович В.Ю. Теоретико-методологічні основи забезпечення національної безпеки України: моногр. у 7 т. Т. 1 : Теоретичні основи, методи й технології забезпечення національної безпеки України / В.Ю. Богданович, І.Ю. Свида, С.Д. Скулиш. - К.: Наук.-вид. відділ НА СБ України, 2012. - 548 с.

10. Богданович В.Ю. Аналіз можливостей системи забезпечення національної безпеки України щодо всебічної підтримки безпекового супроводу реалізації національних інтересів / В.Ю. Богданович, І.Ю. Свида, А.Л. Висідалко // Наука і техніка Повітряних сил Збройних Сил України. - 2013. - № 3(12). - С. 5-12.

11. Богданович В.Ю. Методика автоматизованого моделювання експертно-аналітичних сценаріїв виявлення та усунення загроз реалізації національних інтересів / В.Ю. Богданович, А.Л. Висідалко // Наука і техніка Повітряних сил ЗС України. - 2015. - № 3(20). - С. 21-29.

12. Богданович В.Ю. НАТО и Украина (Кто и зачем тянет Украину в НАТО) / В.Ю. Богданович, Ю.В. Егоров, А.Я. Маначинский. - К. : Изд. Дом “Румб”, 2008. - 200 с.

13. Корнилов В. План внешнего управления Украиной [Електронний ресурс] / В. Корнилов - Режим доступу: http://cis.org.ua/content/ view/142/1/.

14. Богданович В. Граф-модель гибридной агрессии государства-инициатора против выбранного государствамишени [Электронный ресурс] / В. Богданович // SDirect 24 -Safety, Society, Science. - 2020. - № 1(12). - Режим доступу: https://www.sdirect24.org/kopia-nato-deep-no-11.

15. Богданович В.Ю. Методика формування групи суб'єктів сектора безпеки і оборони для комплексної протидії виявленій (прогнозованій) загрозі / В.Ю. Богданович, І.Ю. Свида, А.М. Сиротенко // Зб. наук. пр. ЦНДІ ЗС України. 2018. - № 2(84). - С. 33-43.

16. Богданович В.Ю. Методика формування та управління інтегрованим потенціалом протидії загрозам воєнного характеру для забезпечення визначеного рівня воєнної безпеки держави / В.Ю. Богданович, І.Ю. Свида, А.М. Сиротенко // Сучасні інформаційні технології у сфері безпеки та оборони: Зб. наук. пр. НУОУ ім. Івана Черняховського. - 2018. № 2(32). - С. 81-86.

17. Чекинов С.Г. Асимметричные действия по обеспечению военной безопасности / С.Г. Чекинов, С.А. Богданов // Военная мысль. - 2010. - № 3. - С. 13-22.

18. Власюк О.С. Національна безпека України: еволюція проблем внутрішньої політики: вибр. наук. праці / О.С. Власюк. - К.: НІСД, 2016. - 528 с.

19. Богданович В.Ю. Методичний підхід до визначення необхідних спроможностей складових інтегрованого потенціалу протидії загрозам на виконавчому рівні / В.Ю. Богданович, А.М. Прима // Наука і техніка Повітряних сил Збройних Сил України. - 2017. - № 2(27). - С. 162-166. https://doi.org/10.30748/nitps.2017.27.31.

\section{References}

1. Decree of the President of Ukraine (2015), "Pro Stratehiju nacionaljnoi bezpeky Ukrajiny" No. 287/2015 vid 06.05.2015" [The National Security Strategy of Ukraine No. 287/2015 dated 06.05.2015], Kyiv, 45 p.

2. Decree of the President of Ukraine (2016), "Pro rishennja Rady natsionaljnoji bezpeky i oborony Ukrainy vid 4 bereznja 2016 roku "Pro Kontseptsiju rozvytku sektoru bezpeky i oborony Ukrainy" No. 92/2016" [The concept of development of the security and defense sector of Ukraine No. 92/2016 dated 14.03.2016], Kyiv, 17 p.

3. The Low of Ukraine (2015), "Pro osnovi nacionalnoyi bezpeki" No. 964-IV vid 19.06.2003 (iz zminami, vnesenimi zgidno iz Zakonom No. 186-VIII vid 12.02.2015)" [On the Fundamentals of National Security No. 964-IV dated June 19, 2003 (as amended in accordance with the Law No. 186-VIII dated February 12, 2015], Uryadovij kur'yer, No. 15. 
4. The Low of Ukraine (2018), "Pro nacionalnu bezpeku Ukrayini" No. 2469-VIII vid 21 chervnya 2018" [On the National Security of Ukraine No. 2469-VIII dated June 21, 2018], Golos Ukrayini, No. 122 (6877), 31 p.

5. Decree of the President of Ukraine (2015), "Pro rishennja Rady natsionaljnoji bezpeky i oborony Ukrainy vid 2 veresnja 2015 roku "Pro novu redaktsiiu Voiennoi doktryny Ukrainy" No. 555/2015" [On the Decision of the National Security and Defense Council of Ukraine dated September 2 "On the new edition of the Military Doctrine of Ukraine” No. 555 /2015], Kyiv, $24 \mathrm{p}$.

6. Bohdanovych, V.Yu., Romanchenko, I.S., Svyda, I.Yu. and Syrotenko, A.M. (2019), “Metodolohiia kompleksnoho vykorystannia viiskovykh neviiskovykh syl i zasobiv sektora bezpeky i oborony dly protydii suchasnym zahrozam voiennii bezpetsi Ukrainy" [Methodology of integrated use of military and non-military forces and means of the security and defense sector to counteraction modern threats to Ukraine's military security], NUOU im. I. Cherniakhovskoho, Kyiv, 268 p.

7. Bohdanovych, V.Yu., Svyda, I.Yu. and Skulysh, Ye.D. (2012), "Teoretyko-metodolohichni osnovy zabezpechennia natsionalnoi bezpeky Ukrainy. T. 4.Vojenna bezpeka Ukrajiny ta shljakhy jiji zabezpechennja" [Theoretical and methodological bases of ensuring the National Security of Ukraine. Vol. 4. Military security of Ukraine and ways to ensure it], Nauk.-vyd. Viddil NA SB Ukrainy, Kyiv, 464 p.

8. Sarichev, Yu.O. (2017), "Informacijno-analitichne zabezpechennya yak vid informacijnogo zabezpechenny v sistemi derzhavnogo upravlinnya" [Information and analytical support as a type of information support in the system of public administration], Visnik NADU pri Prezidentovi Ukrayini (Seriya “Derzhavne upravlinnya”), No. 3, pp. 120-126.

9. Bohdanovych, V.Yu., Svyda, I.Yu. and Skulysh, Ye.D. (2012), "Teoretyko-metodolohichni osnovy zabezpechennia natsionalnoi bezpeky Ukrainy. T. 1. Teoretychni osnovy, metody y tekhnolohii zabezpechennia natsionalnoi bezpeky Ukrainy" [Theoretical and methodological bases of ensuring the National Security of Ukraine. Theoretical bases, methods and technologies of ensuring national security of Ukraine. Vol. 1. Theoretical bases, methods and technologies of ensuring national security of Ukraine], Nauk.-vyd. Viddil NA SB Ukrainy, Kyiv, 548 p.

10. Bogdanovich, V.Yu., Svida, I.Yu. and Visidalko, A.L. (2013), "Analiz mozhlivostej sistemi zabezpechennya nacionalnoyi bezpeki Ukrayini shodo vsebichnoyi pidtrimki bezpekovogo suprovodu realizaciyi nacionalnih interesiv" [ Analysis of the possibilities of the National Security system of Ukraine in terms of comprehensive support of security support for the realization of national interests], Science and Technology of the Air Force of Ukraine, No. 3(12), pp. 5-12.

11. Bogdanovich, V.Yu. and Visidalko, A.L. (2015), "Metodika avtomatizovanogo modelyuvannya ekspertno-analitichnih scenariyiv viyavlennya ta usunenny zagroz realizaciyi nacionalnih interesiv" [Methods of automated modeling of expertanalytical scenarios for identifying and eliminating threats to the realization of national interests], Science and Technology of the Air Force of Ukraine, No. 3(20), pp. 21-29.

12. Bogdanovich, V.Yu., Egorov, Yu.V. and Manachinskij, A.Ya. (2008), "NATO i Ukraina (Kto i zachem tyanet Ukrainu v NATO)" [NATO and Ukraine (Who and why is pulling Ukraine into NATO)], Izd. Dom "Rumb", Kyiv, 2000 p.

13. Kornilov, V. "Plan vneshnego upravleniya Ukrainoj" [Ukraine's external governance plan], available at: www.cis.org.ua/content/ view/142/1/.

14. Bogdanovich, V. (2020), "Graf-model gibridnoj agressii gosudarstva-iniciatora protiv vybrannogo gosudarstvamisheni" [Graph-model of hybrid aggression of the initiating state against the selected target-state], SDirect 24 - Safety, Society, Science, No. 1(12), available at: https://www.sdirect24.org/kopia-nato-deep-no-11.

15. Bogdanovich, V.Yu., Svida, I.Yu. and Sirotenko, A.M. (2018), “Metodika formuvannya grupi sub'yektiv sektora bezpeki i oboroni dlya kompleksnoyi protidiyi viyavlenij (prognozovanij) zagrozi" [ Methods of forming a group of subjects of the security and defense sector for comprehensive counteraction to the identified (predicted) threat], Zbirnik naukovikh prats CNDI ZS Ukrayini, No. 2(84), pp. 33-43.

16. Bogdanovich, V.Yu., Svida, I.Yu. and. Sirotenko, A.M. (2018), "Metodika formuvannya ta upravlinnya integrovanim potencialom protidiyi zagrozam voyennogo harakteru dlya zabezpechennya viznachenogo rivnya voyennoyi bezpeki derzhavi" [Methods of forming and managing the integrated potential for counteracting military threats to ensure a certain level of military security of the state], Suchasni informacijni tehnologiyi u sferi bezpeki ta oboroni: Zb. nauk. pr. NUOU im. Ivana Chernyahovskogo, No. 2(32), pp. 81-86.

17. Chekinov, S.G. and Bogdanov, S.A. (2010), "Asimmetrichnye dejstviya po obespecheniyu voennoj bezopasnosti" [Asymmetric actions to ensure military security], Voennaya mysl, No. 3, pp. 13-22.

18. Vlasyuk, O.S. (2016), "Nacionalna bezpeka Ukrayini: evolyuciya problem vnutrishnoyi politiki” [National security of Ukraine: the evolution of internal policy problems], NISD, Kyiv, $528 \mathrm{p}$.

19. Bohdanovych, V.Yu. and Pryma, A.M. (2017), "Metodychnyi pidkhid do vyznachennia neobkhidnykh spromozhnostei skladovykh intehrovanoho potentsialu protydii zahrozam na vykonavchomu rivni" [Methodical approach to determining the necessary capabilities of the components of the integrated potential for countering threats at the executive level], Science and Technology of the Air Force of Ukraine, No. 2(27), pp. 162-166. https://doi.org/10.30748/nitps.2017.27.31. 
Відомості про авторів:

Богданович Володимир Юрійович

доктор технічних наук професор

головний науковий співробітник Центрального

науково-дослідного інституту Збройних Сил України,

Київ, Україна

https://orcid.org/0000-0003-0481-9454

Сиротенко Анатолій Миколайович

доктор військових наук

Начальник Національного університету

оборони України ім. І. Черняховського,

Київ, Україна

https://orcid.org/0000-0002-0266-5706

Дублян Олександр Володимирович

кандидат військових наук

провідний науковий співробітник

Центрального науково-дослідного інституту

Збройних Сил України,

Київ, Україна

https://orcid.org/0000-0001-5129-3913
Information about the authors:

Vladimir Bohdanovych

Doctor of Technical Sciences Professor

Chief Research of Central Research Institute

of the Armed Forces of Ukraine,

Kyiv, Ukraine

https://orcid.org/0000-0003-0481-9454

Anatoliy Sirotenko

Doctor of Military Sciences

Chief of Ivan Chernyakhovsky

National Defense University of Ukraine,

Kyiv, Ukraine

https://orcid.org/0000-0002-0266-5706

Oleksandr Dublayn

Candidate of Military Sciences

Lead Research

of Central Research Institute

of the Armed Forces of Ukraine,

Kyiv, Ukraine

https://orcid.org/0000-0001-5129-3913

\title{
КОНЦЕПЦИЯ АСИММЕТРИЧНОГО ПРОТИВОДЕЙСТВИЯ ВРАЖДЕБНОМУ ГОСУДАРСТВУ ДЛЯ НЕЙТРАЛИЗАЦИИ ЕГО ВЛИЯНИЯ НА ОПРЕДЕЛЯЮЩИЕ СФЕРЫ НАЦИОНАЛЬНОЙ БЕЗОПАСТНОСТИ УКРАИНЫ
}

\author{
(I часть)
}

В.Ю. Богданович, А.М. Сиротенко, О.В. Дублян

В статье обоснованы концептуальные положения организачии асимметричного противодействия агрессии более мощного в военном отнощении государства со стороны государства-жертвы агрессии в интересах защиты своих фундаментальных жизненно важных национальных интересов. Определены организачионно-методические основы обеспечения достаточного уровня военной безопастности с использованием асимметрических действий, а также цели, формы и способы организачии и ведения асимметрических действий, которые направлены на снижение влияния отдельных угроз в важнейших сферах жизнедеятельности государства. Приведено описание обобщенной модели гибридной агрессии (войны) и концептуальной модели итерационного формирования потенщиала ассиметричного противодействия угрозам военной безопасности государства.

Ключевые слова: асимметричное противодействие, военная сила, военная безопасность, еффективность противодействия, вооруженный конфликт, силовое давление, угроза.

\section{THE CONCEPT OF ASYMMETRIC COUNTERACTION TO THE HOSTILE STATE FOR NEUTRALIZATION OF ITS INFLUENCE ON THE DEFINITIVE SPHERES OF NATIONAL SECURITY OF UKRAINE} (Chapter I)

V. Bogdanovich, A. Syrotenko, O. Dublyan

The article substantiates the conceptual theses of the organization of asymmetric counteraction to the aggression of a "powerful" state in militarily sense on the part of the state-victim of aggression in the interests of protection of its fundamental vital national interests. The organizational and methodological foundations of ensuring a sufficient level of military security of the state with the use of asymmetric actions, as well as goals, forms and methods of organizing and conducting asymmetric actions aimed at reducing the impact of certain threats on key areas of state life. Organizational and methodological foundations allow to scientifically substantiating the organization and formation of a system of counteraction to these threats by asymmetric actions, which may include the actions of the Special Operations Forces, foreign intelligence, information influence in various forms, as well as political, economic and other non-military influences. The main form of application of the subjects of asymmetric counteraction is proposed to be considered a "special operation" as "coordinated actions of disparate forces and means united by a single goal". A special operation is carried out to achieve the strategic goal of counteraction. Its component can be a "local special operation" as a form of achieving certain tactical objectives of counteraction. The main ways to form the integrated potential of asymmetric counteraction: it is proposed to consider the integration of military and non-military forces and means with priority given to non-force means with the use of force to support and integration with priority to force means with the use of non-force to support. The description of the generalized model of hybrid aggression (war) and conceptual model of iterative formation of potential of asymmetric counteraction to threats to military security of the state is resulted. The offered model allows solving both a direct problem and means to ensure the normatively established level of military security of the state.

Keywords: asymmetric counteraction, military power, military security, threat, armed conflict, force pressure, counteraction efficiency. 